EDITORIAL

\title{
LEGAL DEVELOPMENT AND GLOBALIZATION: SOME CONTEMPORARY ISSUES IN INDONESIA AND GLOBAL CONTEXT
}

\author{
Ridwan Arifin \\ Universitas Negeri Semarang, Managing Editor Journal of Law and Legal Reform \\ $\bowtie$ ridwan.arifin@mail.unnes.ac.id
}

When there is society, there always law, ubi societas ibi ius, has been impressed us that society always changes everyday and it impacted to the law enforcement itself. The inability of the law to respond the rapid changes even disruptive changes in the society raises its own problems in one hand, and challenges in the other hands.

At this third issue, Journal of Law \& Legal Reform Volume 1 Issue 3 (April 2020) presents some articles both original research articles and review articles from various institution and country. At this issue, the editor team highlight the focus theme "Law and Development in Disruptive Era (Indonesia and Global Context)" to give a high impression that this volume not only debating the contemporary issues concerning to legal development, but also the impact of law changes or law reform in the society itself.

This Volume presents nine research articles and four review articles from Indonesia and Nigeria. Some articles highlight a very interesting issues, and some other very controversial issues in law changes in society and its implication. Article written by Muhajirin \& Ismail, Theft with Violence in Criminology Aspect: How People Dealing with Law, highlights the aspect of criminology in theft crime. They exposed how someone can be theft and what factors affected. They used some criminology theories to analyze the facts and conditions. 
Another papers, Effectiveness of Treatment and Recovery of Domestic Violence Victims on Semarang Regency, written by Christophorus Divo Shubma Cahyaningutomo tried to expose the phenomenon of domestic violence in Indonesia especially in Semarang Regency and how the protection for the victims of that crime. He elaborated some data and theories concerning to victim protections, and how government provide an equal justice and protection for victims of domestic violence. From his research, $\mathrm{He}$ emphasized that supporting facilities for victims has been conducted by several institution.

Implementation of Counseling by Bhabinkamtibmas in Preventing the Spread of Hoax in Kebumen Police Station, written by Reyhan Kusuma and The Role of the Nusantara Task Force in Preventing Political Vulnerability in the Pati Police Jurisdiction, by Arindra Wigrha Pratama have different perspectives. They analyze the Police Roles to maintain the public security in certain Police Jurisdiction. Reyhan Kusuma highlights the role of Bhabinkamtibmas as one of units in Police Department on preventing hoax and fake news in the society. He analyzed, how this unit progressively decrease the spreading of hoax news in one hand and increase the public awareness to social medias and good news in another hands. In the same context, Arindra Wigrha Pratama exposed and analyzed the role of Nusantara Task Force as one of units in Police Department to prevent the political vulnerability in Pati Central Java. He analyzed some impacts post General Elections in Indonesia.

Nur Kholis, Parliamentary Threshold and Political Rights Limitation, has same perspective with previous paper, Arindra Wirgha Pratama. Both Kholis and Pratama analyzed concerning to political rights, as well as political vulnerability. However, Nur Kholis analyzed from the context of constitutional and administrative law, where he explained the impacts of parliamentary threshold from political rights concept. He highlighted that parliamentary threshold in one hand has been limited the rights of people especially political rights, but another hands its give more effective and efficient for democracy in Indonesia.

Another papers, Protection of Disaster Responsibilities in the Central Java Province: How the Law Protect the Volunteer, written by Hilda Maulida, Position of the Victim in Criminal Acts Illegal Logging by Redentor G.A. Obe, Ali Masyhar, Political Implications of the Law in the Formation of Law No. 13 of 2003 concerning Workers Protection in Employment Agreement Specific Time (EAST/PWKT) by Muhammad Bram Glasmacher, Dynasty Politics in Indonesia: Tradition or Democracy by Hagi Utomo Mukti, Rodiyah, Dani Muhtada, and Press Roles in Democracy Society by Lailasari Ekaningsih 
In this third edition, we present thirteen papers (Research and Review Articles) and one Current Commentary. We thank all the authors, contributors and Reviewers who were involved directly or indirectly in the preparation and publication of this third edition. In addition, our gratitude also goes to the Indonesian Legal Journal Management Association (APJHI) for all its support, and the Law Masters Study Program at the Faculty of Law, Semarang State University.

I personally thank Dr. Rodiyah SPd SH MSi (Dean of the Faculty of Law), Dr. Indah Sri Utari SH MHum (Chair of the Master of Laws Program), and the entire Team of the Journal of Law and Legal Reform. This year, the Journal of Law and Legal Reform continues to improve the quality of journal content and online journal page display with several national and international indexations.

We also would like to extend our thankfulness to all Reviewers, Editorial Boards, and Associate Editors of Journal of Law and Legal Reform for their invaluable support. After Professor Frankie Young from Ottawa University, Canada, we also reached the collaboration with Palermo University Italy.

Furthermore, we also would like to inform all Authors and Readers, that starting 2020, our Journal has been indexed by DOAJ System, we also have intimate cooperation with several agencies in improving the quality of journals, among the General Election Supervision Board, several Law Firms, Government Agencies, and several Non-Governmental Organizations in participating in providing input and suggestions for the future development of our journal. We also provide wide opportunities for anyone who has an interest in our journal. We hope that, through the publication of this third edition of the journal, it will be able to contribute to legal scholarship and discourse on the development of law in Indonesia in a global context.

Due to our university policy concerning to paperless policy, we cannot provide the print version of the Journal for all authors. However, Author can download the full version of the issue at the journal's website (ready to print file), also with the certificate of authorship and letter of acceptance that can be downloaded directly on our website (online certificate). 


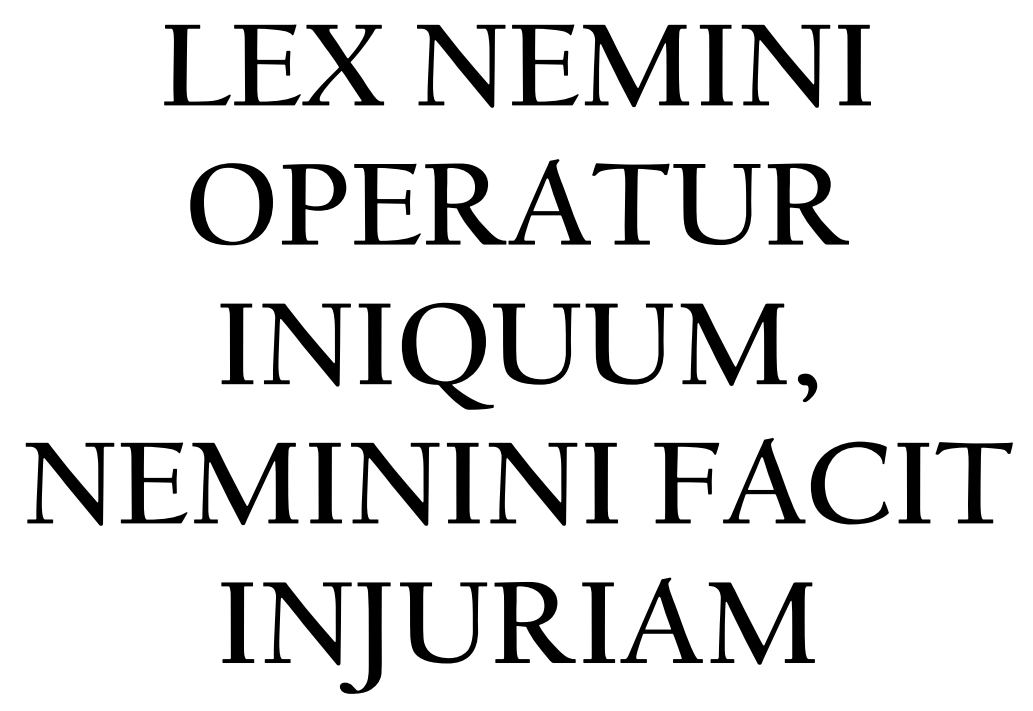

The law works an injustice
to no one and does wrong to
no one 